\title{
Plant inhabiting mites (Acari) from the Cerrado biome of Mato Grosso State, Brazil
}

\author{
PETERSON R. DEMITE ${ }^{1,5}$, REINALDO J.F. FERES ${ }^{2,4}$, ANTONIO C. LOFEGO ${ }^{2} \&$ ANIBAL R. \\ OLIVEIRA $^{3}$ \\ ${ }^{1} P P G$ - Biologia Animal, UNESP-Universidade Estadual Paulista, São José do Rio Preto, SP, Brazil \\ ${ }^{2}$ Depto. de Zoologia e Botânica, UNESP-Universidade Estadual Paulista, Rua Cristóvão Colombo, 2265, Jardim Nazareth, 15054- \\ 000, São José do Rio Preto, SP, Brazil \\ ${ }^{3}$ Depto. de Ciências Agrárias e Ambientais, UESC-Universidade Estadual de Santa Cruz, Rodovia Ilhéus-Itabuna, km 16, Ilhéus, BA, \\ Brazil \\ ${ }^{4}$ CNPq-Brazil Researcher \\ ${ }_{5}^{5}$ Corresponding author: E-mail: peterson_demite@yahoo.com.br
}

\begin{abstract}
This study reports on the mites associated with plants in two Cerrado formations: Cerradão and Riparian Forest, located in Itiquira, in the southern region of Mato Grosso State, Brazil. A total of 67 mite species was collected, belonging to 20 families in the suborders Gamasida, Actinedida, Acaridida and Oribatida. Phytoseiidae (13 species) and Tarsonemidae (11 species) were the families with the greatest richness. Iphiseiodes zuluagai (Denmark \& Muma) (Phytoseiidae), Lamellobates (Lamellobates) sp. (Oribatida, Austrachipteriidae) and Agistemus sp. (Prostigmata, Stigmaeidae) were the most frequent species, collected on eleven, ten and nine plant species, respectively. Among the plants found during the fieldwork, the plant species Bauhinia longifolia (Bong.) Steud. (Caesalpinaceae), collected in the Riparian Forest formation, contained the highest species richness (28 species). The specific identification of approximately $70 \%$ of the taxa collected was not possible. For these reasons, surveys of mites in natural areas that include estimates of the ratio of undescribed species are important, because they provide a panorama of the great diversity of unknown mite fauna in these environments.
\end{abstract}

Key words: Acari, biodiversity, Cerrado, native fragments, Neotropical Region, Brazil

\section{Introduction}

The Cerrado is the second largest Brazilian biome, surpassed only by the Amazon Rainforest (Ribeiro \& Walter 1998). It covers an area of approximately 2 million $\mathrm{km}^{2}$, representing nearly $22 \%$ of the Brazilian territory (Oliveira-Filho \& Ratter 2002). The typical vegetation of the Cerrado is made up of low twisted trees with irregular and contorted branches. However, the ecosystems of the Cerrado biome range from forest formations with canopies to open fields with a predominance of herbaceous and rare bushes, and an absence of trees (Ribeiro \& Walter 1998). Due to the great concentration of endemic species, this biome is considered as a "hotspot", one of the priority conservation areas (Myers et al. 2000).

According to Aguiar et al. (2004), scientific knowledge on the Cerrado is still at a very early stage. Some surveys of the mites associated with native plants have been carried out in São Paulo State (Flechtmann 1967a; Aranda 1974; Lofego \& Moraes 2003, 2006; Lofego et al. 2004, 2005, 2007; Oliveira et al. 2005). However, São Paulo only contains $4 \%$ of the total area of that biome in the country, and the remainder of the area is unexplored. 